\title{
Evaluation of Aflatoxin B1 in poultry feeds marketed in Nsukka agricultural zone, Enugu state, South Eastern Nigeria
}

\author{
${ }^{* 1}$ Ozioko, C. A, ${ }^{2}$ Chah, F. K. \& ${ }^{3}$ Okafor. J. I. \\ ${ }^{1 *}$ Department of Veterinary Microbiology, Michael Okpara University of Agriculture,Umudike, Abia State. ${ }^{2}$ Department of \\ Veterinary Microbiology, University of Nigeria Nsukka, ${ }^{3}$ Department of Microbiology, University of Nigeria Nsukka, Nigeria \\ *Corresponding author: christiananene333@gmail.com; +234 08065997219
}

\begin{abstract}
Aflatoxin contamination of poultry feeds is a major challenge to profitable poultry productivity and trade. This study was carried out to evaluate the levels of aflatoxin B1 (AFB1) contamination of poultry feeds commonly sold in Nsukka, Enugu State, Nigeria. A total of 48 representative feed samples, comprising 24 toll-milled and 24 commercial feeds, were collected. aflatoxin B1 was detected in all (100\%) the samples analysed using Indirect Competitive ELISA technique at various concentrations, with AFB1 concentrations of toll-milled and commercial feeds samples ranging from $2.5-473.8 \mathrm{ppb}$ and $1.1-$ $1683.2 \mathrm{ppb}$, respectively. The mean AFB1 concentration $(77.69 \pm 19.36 \mathrm{ppb})$ of toll-milled feed samples was significantly less $(\mathrm{p} \leq 0.05)$ than the mean AFB1 concentration of commercial feeds brands $(231.10 \pm 71.1 \mathrm{ppb})$. The mean AFB1 concentration of commercial brand A feeds $(12.11 \pm 3.25 \mathrm{ppb})$ was significantly less $(\mathrm{p}<0.05)$ than the mean concentrations of commercial brand B feeds (385.91 $\pm 152 \mathrm{ppb})$ and brand C feeds (425.90 $\pm 97.93 \mathrm{ppb})$. The toll-milled and commercial feeds samples evaluated showed that $79.17 \%$ and $70.8 \%$ of the feeds, respectively, had AFB1 concentrations above the United State Food and Drugs Administration action value, $20 \mathrm{ppb}$. The levels of AFB 1 contaminations in the feed samples studied were high, and thus make the feeds unsafe for poultry consumption. Therefore, there is need for routine screening and monitoring of AFB1 in poultry feeds marketed in this area to avoid high levels of AFB1 in feeds and the subsequent accumulation in the poultry products.
\end{abstract}

Keywords: Aflatoxin B1, Commercial feed, ELISA, Poultry, Toll-milled feed.

\section{INTRODUCTION}

Poultry feeds may contribute to the transfer of certain poisons and toxins such as mycotoxins, heavy metals, drug residues, pesticides and microbiological hazards into the food chain, thereby raising global concern about feed safety. Mycotoxins are poisonous chemical compounds and secondary metabolites produced by fungi (Tola \& Kebede, 2016). These secondary metabolites which are produced by filamentous genera of fungi have harmful effects on animals and humans following consumption of contaminated animal feeds and animal products, respectively (WHO, 2006; Mostafa et al., 2012). Aflatoxins are considered the most common mycotoxin in poultry production (Leggieri et al., 2015). Aflatoxin B1 (AFB1), produced by Aspergillus flavus and Aspergillus parasiticus, is of major concern in poultry production (Magnoli et al., 2011). Aspergillus flavus is found more frequently in contaminated feeds than Aspergillus parasiticus (Varga et al., 2011).

Animal feed industries compete for feed materials with humans, thus low-quality raw materials/ingredients are often used for poultry feed production (Abidin et al., 2011). Abidin et al., (2011) reported that the major challenge faced by International as well as local feed industries is the high cost of feed production due to competition for feed materials by humans and animals. In Nigeria, food ingredients unfit for human consumption are normally utilized for feed production. The poultry sector, therefore, is at risk of economic losses due to negative impact of aflatoxins on their performance (Marchioro et al., 2013; Atherstone et al., 2016).

Poultry have been reported to be very sensitive to the effects of aflatoxin B1 (Denli \& Okon, 2006). Acute toxicity in 
poultry results in death whereas chronic toxicity is characterized by damage to the liver, lower profitability and break in immunity, leading to heavy economic losses (Abdullah et al., 2010). Aflatoxin B1 in poultry tends to accumulate in poultry meat and eggs; and is finally transferred to humans after consuming these products (Oliveira et al., 2006; Abdullah et al., 2010). Meat contaminated with aflatoxin causes depression, nervousness, pain, diarrhoea, liver toxicity, cancer and even death (Abdullah et al., 2010). Different countries have established different standards to govern aflatoxin levels in human and animal feeds. The limits of Aflatoxin B1 and total Aflatoxins in foods are $2 \mu \mathrm{g} / \mathrm{kg}$ and $4 \mu \mathrm{g} / \mathrm{kg}$, respectively in the European Union whilst they are $5 \mu \mathrm{g} / \mathrm{kg}$ and $10 \mu \mathrm{g} / \mathrm{kg}$, respectively, in more than 75 countries around the world (Herzallah, 2009). World Health Organization (WHO) has set aflatoxins limits for animal feeds at $5 \mu \mathrm{g} / \mathrm{kg}$ (Kajuna et al., 2013) and Food and Drug Administration (FDA) at $20 \mu \mathrm{g} / \mathrm{kg}$ (Reddy \& Raghavender, 2007).

The aim of this study is to evaluate the levels of aflatoxin B1 in toll-milled and commercial brands of poultry feeds used in Nsukka Agricultural zone of Enugu state, Nigeria accounts for approximately $35 \%$ of females culled from

\section{MATERIALS AND METHODS}

\section{STUDY AREA}

Nsukka Agricultural zone of Enugu state is a zone in southeast of Nigeria, located in a tropical rainforest between latitude $5^{\mathrm{O}} 56-7^{\mathrm{O}} 60 \mathrm{~N}$ and longitude $6^{\mathrm{O}} 53$ and $7^{\mathrm{O}} 55 \mathrm{E}$. The average annual rainfall in the zone is around 2,000 millimeter (Egboka, 1985). The climate is humid and humidity is at its highest between March and November. The mean daily temperature is $26.7^{\circ} \mathrm{C}\left(80.1^{\circ} \mathrm{F}\right)$.

\section{SAMPLE COLLECTION}

A total of forty-eight (48) feed samples comprising 24 tollmilled feeds and 24 commercial feeds (brand A, B and C) were collected from the two toll-milled feed producers and three major commercial feed distributors in the zone from May, 2012 to August, 2013. Commercial brand A feeds were collected from Top feeds distributor whereas commercial brand B and C feeds were collected from Vital and Unique feeds distributors, respectively. The representative samples were collected batch by batch using systematic random sampling technique. Sampling plan was carried out according to Food and Agricultural Organisation (FAO, 1993), by taking ten $100 \mathrm{~g}$ samples from each batch and mixing together.

\section{EXTRACTION OF AFLATOXIN B1 IN FEED SAMPLES}

The Aflatoxin b1 (AFB1) concentrations in the feed samples were determined using indirect competitive ELISA (AflaELISA) technique (Lava \& Bandyopadhyay, 2012). The representative samples of the feeds were pulverized using grinding machine with $1 \mathrm{~mm}$ sieve. Ten gram $(10 \mathrm{~g})$, from each of the ground representative samples, was mixed with $50 \mathrm{ml}$ of the extraction reagent (70\% Methanol). The mixtures were homogenized using Orbiter shaker at $300 \mathrm{rpm}$ for 30mins. The homogenized mixtures were filtered with Whatmann filter paper placed in a funnel and the filtrates collected in flat bottom conical flasks. The filtrates (extracts) were used for the ELISA test.

\section{AFLATOXIN B1 DETECTION}

The ELISA microtiter plates (Nunc-Maxisorp) were coated with $100 \mathrm{ng} / \mathrm{ml}$ Aflatoxin B1-Bovine Serum Albumen (AFB1-BSA) buffer (Sigma A 6655). Each well was coated with $150 \mu 1$ of the AFB1-BSA and incubated for 60 minutes at $37^{\circ} \mathrm{C}$. The coated plates were washed three times with phosphate buffered solution (PBS) and allowed to dry. Thereafter, the coated plates were blocked with $0.2 \mathrm{ng} / \mathrm{ml}$ Bovine Serum Albumin (BSA) in PBS buffer for 30 minutes and washed once with PBS. The samples (extracts) were diluted in BSA buffer. One hundred microliter $(100 \mu 1)$, each of the diluted samples, was pipetted and loaded into the ELISA plate wells in replicates. One hundred microliter of BSA was loaded in each of the wells in the first two rows. Then $100 \mu \mathrm{l}$ of the standard (known concentration) was loaded into the first two wells, in replicate, in the first two rows, and serially diluted in the BSA. The control (extract from healthy maize) was loaded into the last two wells, in replicate, in the first two rows. In each of the loaded wells, $150 \mu 1$ of the enzyme conjugate (antibody) was added. Also, $150 \mu \mathrm{l}$ of Alkaline phosphatase conjugate was added in each of the loaded wells and incubated in a mechanical incubator at $37^{\circ} \mathrm{C}$ for 1 hour. Thereafter, the plates were washed in PBS and $150 \mu 1$ of the enzyme substrate, para-nitrophenylphosphate (Sigma N 2640) was added in each of the well. The plates were kept in the darkroom for 30 minutes before the readings were taken using ELISA (micro well) reader with $405 \mathrm{~nm}$ filter. The reader determined the optical densities of the samples, the standard and control. Using the values obtained for Aflatoxin b1 standards, a curve was drawn with the help of a computer (Microsoft office Excel), taking aflatoxin concentrations on the " $X$ " axis and the optical density values on the " $Y$ " axis. The concentrations of aflatoxin B1 in the samples were calculated from the standard graph by tracing the concentration on the graph that corresponded with the optical density on the X-axis. The Aflatoxin B1 concentration per kilogram of the samples was calculated as follow: 
$\operatorname{AFB} 1(\mu \mathrm{g} / \mathrm{kg})=\frac{A X D X E}{G}$ or $\frac{A X E}{C X G}$

$\mathrm{A}=\mathrm{AFB} 1$ concentration in diluted or concentrated sample extract (ng/ml).

$\mathrm{D}=$ degree of dilution with buffer.

$\mathrm{C}=$ concentration after clean-up.

$\mathrm{E}=$ extraction solvent volume used $(\mathrm{ml})$.

$\mathrm{G}=$ sample weight $(\mathrm{g})$.

\section{DATA PRESENTATION AND STATISTICAL ANALYSIS}

Data generated in this study were presented in tables, graphs and mean \pm SEM. Data on the differences in the mean aflatoxin B1 concentration in toll-millled and commercial feed samples and between the two brands of commercial feed samples were determined using student t-test. The significant difference and variation in means were separated using Fischer Least significant difference (LSD) at 5\% probability level.

\section{RESULTS}

The indirect competitive ELISA results from this study showed that all the poultry feed samples $(100 \%)$ evaluated contained various concentrations of aflatoxin B1. Both the commercial feeds and the toll-milled feeds had $100 \%$ contamination.

The aflatoxin B1 concentrations in the toll-milled feed samples ranged from 2.5 to $473.8 \mathrm{ppb}$ (Figure I). Five (20.8\%) feed samples out of the 24 Toll-milled feed samples had AfB1 concentrations less than the United State Food and Drug Administration (USFDA) maximum permissible limit, $20 \mu \mathrm{g} / \mathrm{kg}$, in feeds. Nineteen $(79.2 \%)$ feed samples out of the 24 toll-milled feed samples had various AFB1 concentrations above the USFDA maximum permissible level (Table I and Table V). The mean AFB1 concentration of the toll-milled feed samples was $77.69 \pm 19.36 \mathrm{ppb}$ (Table II).

The aflatoxin B1 concentrations of the commercial feeds samples ranged from 1.1 to $1683.2 \mathrm{ppb}$ (Figure 2). The least AFB1 concentration, $1.1 \mathrm{ppb}$, was found in commercial brand A feed sample, with $70 \%$ of the brand A feed samples having AFB1 concentrations less than USFDA maximum permissible limit $(20 \mu \mathrm{g} / \mathrm{kg})$ (Table III). The commercial brand $\mathrm{C}$ feed samples showed high levels of AFB1 contamination (Table III) and the highest mean AFB1 concentration $(425.90 \pm 97.93 \mathrm{ppb})($ Table IV). The mean AFB1 concentration of the commercial feed samples was $231.10 \pm 71.1 \mathrm{ppb}$ (Table II).
Table I: The various ranges of AFB1 concentrations (ppb) and the number $(\%)$ of Toll-milled and commercial poultry feed samples within the ranges.

\begin{tabular}{lcc}
\hline $\begin{array}{l}\text { AFB1 } \\
\text { Range } \\
\text { ppb })\end{array}$ & $\begin{array}{l}\text { Number }(\%) \text { of } \\
\text { Toll-milled feeds } \\
\text { within the range } \\
(\mathrm{N}=24)\end{array}$ & $\begin{array}{l}\text { Number } \begin{array}{l}\text { Commercial } \\
\text { within } \\
24)\end{array} \\
\text { of range } \\
\text { feeds } \\
(\mathrm{N}=\end{array}$ \\
\hline $0.1-20$ & $5(20.8)$ & $7(29.2)$ \\
$21-40$ & $6(25)$ & $4(17.7)$ \\
$41-60$ & $0(0)$ & $0(4.2)$ \\
$61-80$ & $5(20.8)$ & $0(0)$ \\
$81-100$ & $1(4.2)$ & $2(8.3)$ \\
$101-200$ & $6(25)$ & $1(4.2)$ \\
$201-300$ & $0(0)$ & $2(8.3)$ \\
$301-400$ & $0(0)$ & $5(20)$ \\
$401-500$ & $1(4.2)$ & $2(8.3)$ \\
$>500$ & $0(0)$ &
\end{tabular}

The mean AFB1 concentration of the toll-milled feeds (77.69 $\pm 19.36 \mathrm{ppb})$ was significantly $(\mathrm{p} \leq 0.05)$ less than the mean aflatoxin B1 concentration $(231.10 \pm 71.1 \mathrm{ppb})$ of the commercial feeds (Table II). The mean aflatoxin B1 concentration of the commercial brand A feed samples were $12.11 \pm 3.25 \mathrm{ppb}$ whereas the mean aflatoxin B1 concentrations of the commercial brand $\mathrm{B}$ and $\mathrm{C}$ were $385.91 \pm 152 \mathrm{ppb}$ and $425.90 \pm 97.93 \mathrm{ppb}$, respectively (Table IV). The mean aflatoxin B1 concentration of the commercial brand A was significantly less $(\mathrm{p} \leq 0.05)$ than the mean aflatoxin $\mathrm{B} 1$ concentrations of the commercial brand $\mathrm{B}$ and $\mathrm{C}$. The mean aflatoxin $\mathrm{B} 1$ concentration of the commercial brand A feed samples were less than USFDA action value, $20 \mu \mathrm{g} / \mathrm{kg}$.

Table II: The mean AFB1 concentrations of Tollmilled and commercial feed samples ppb (part per billion)

\begin{tabular}{ccc}
\hline Feed samples & $\begin{array}{c}\text { Mean } \pm \text { SEM } \\
\text { concentrations of } \\
\text { AFB1 (ppb) }\end{array}$ & P-value \\
& & \\
\hline
\end{tabular}

$\begin{array}{ccc}\text { Toll-milled } & 77.70 \pm 19.4^{\mathrm{a}} & 0.05 \\ \text { Commercial } & 231.10 \pm 71.7^{\mathrm{b}} & 0.05\end{array}$

$a, b=$ superscripts, means with different superscripts significantly varied at $5 \%$ level of significance. 
The toll-milled and commercial feeds samples evaluated showed that $79.17 \%$ (19) and $70.8 \%$ (17) of the feeds had aflatoxin B1 concentrations above $20 \mathrm{ppb}$, respectively (Table I). Seven (70\%) out of the ten feed samples of the commercial brand A had aflatoxin B1 less than 20ppb whereas none of the feed samples of the commercial brand $\mathrm{B}$ and $\mathrm{C}$ had aflatoxin B1 less than 20 ppb (Table III and Table $\mathrm{V})$.

Table III: The various ranges of AFB1 concentrations (ppb) and the number $(\%)$ of the three brands of commercial poultry feed samples within the ranges.

\begin{tabular}{|c|c|c|c|}
\hline \multirow[t]{3}{*}{$\begin{array}{l}\text { AFB1 range } \\
\text { (ppb) }\end{array}$} & \multirow{2}{*}{$\begin{array}{l}\text { Number } \\
(\%) \text { of } \\
\text { Commercial }\end{array}$} & $\begin{array}{ll}\text { Number } & \\
(\%) & \text { of }\end{array}$ & $\begin{array}{l}\text { Number } \\
(\%) \quad \text { of }\end{array}$ \\
\hline & & Commercial & Commercial \\
\hline & $\begin{array}{l}\text { brand A } \\
\text { within } \\
\text { range } \\
(\mathbf{N}=10)\end{array}$ & $\begin{array}{l}\text { brand B) } \\
\text { within } \\
\text { range } \\
(\mathbf{N}=10)\end{array}$ & $\begin{array}{l}\text { brand B) } \\
\text { within } \\
\text { range } \\
(\mathbf{N}=4)\end{array}$ \\
\hline $0.1-20$ & $7(70)$ & $0(0)$ & $0(0)$ \\
\hline $21-40$ & $3(30)$ & $1(10)$ & $0(0)$ \\
\hline $41-60$ & $0(0)$ & $1(10)$ & $0(0)$ \\
\hline $61-80$ & $0(0)$ & $0(0)$ & $0(0)$ \\
\hline $101-200$ & $0(0)$ & $2(20)$ & $0(0)$ \\
\hline $201-300$ & $0(0)$ & $1(10)$ & $0(0)$ \\
\hline $301-400$ & $0(0)$ & $2(20)$ & $0(0)$ \\
\hline $401-500$ & $0(0)$ & $2(20)$ & $3(75)$ \\
\hline$>500$ & $0(0)$ & $1(10)$ & $1(25)$ \\
\hline
\end{tabular}

\section{DISCUSSION}

The results show that all the feed samples (100\%) investigated contained detectable amount of aflatoxin B1 with indirect competitive ELISA. ELISA technique is well favoured as high through-put assay with low sample volume requirement and often less sample clean up procedures compared to other conventional methods such as Thin layer chromatography TLC) and high-performance liquid chromatography (HPLC). ELISA methods are rapid, simple, specific, sensitive and portable for use in the field and have become the most common quick methods for the detection of mycotoxins in feeds and foods (Trucksess, 2001). Several studies have indicated a similar high prevalence of aflatoxins in poultry feeds in different localities. Sixty-eight $(68 \%)$ percent of the total commercial poultry feeds (340) evaluated by indirect ELISA in a tropical country, Morogoro, Tanzania, was contaminated by aflatoxin B1 (Kajuna et al., 2013); whereas as high as $91.1 \%$ contamination of poultry feeds from farms with mean value of $179.1 \mu \mathrm{g} / \mathrm{kg}$ was reported in Iraq (Shareef, 2010). Also, 83\% contamination of poultry feed samples by aflatoxin B1 at mean concentration of $74 \mu \mathrm{g} / \mathrm{kg}$ was reported in south-western Nigeria (Oyekemi et al., 2012). A study conducted for a
Table IV: The mean aflatoxin B1 concentrations in the three brands of commercial poultry feed samples.

ppb (part per billion)

\begin{tabular}{|c|c|c|}
\hline Feed type & $\begin{array}{c}\text { Mean } \pm \text { SEM } \\
\text { AFB1 } \\
\text { concentration } \\
(p p b)\end{array}$ & $\begin{array}{c}P \\
\text { value }\end{array}$ \\
\hline $\begin{array}{l}\text { Commercial brand A } \\
(\mathrm{n}=10)\end{array}$ & $12.11 \pm 3.25^{\mathrm{a}}$ & 0.05 \\
\hline $\begin{array}{l}\text { Commercial brand B } \\
(\mathrm{n}=10)\end{array}$ & $385.91 \pm 152.0^{\mathrm{b}}$ & 0.05 \\
\hline $\begin{array}{l}\text { Commercial brand C } \\
(\mathrm{n}=4)\end{array}$ & $425.90 \pm 97.93^{b}$ & 0.05 \\
\hline $\begin{array}{l}\text {-year period in Keny } \\
\text { oles were contaminated }\end{array}$ & $\begin{array}{l}\text { reported that all an } \\
\text { with aflatoxins; ninet }\end{array}$ & $\begin{array}{l}\text { al feed } \\
\text { ive }\end{array}$ \\
\hline \multicolumn{3}{|c|}{$\begin{array}{l}\text { Table V: The percentage of poultry feed samples } \\
\text { with aflatoxin B1 level above the Food and Drug } \\
\text { Authority accepted level }(20 \mu \mathrm{g} / \mathrm{kg}) \text {. }\end{array}$} \\
\hline Feed type & $\begin{array}{r}\text { Percentage of sam } \\
\text { Aflatoxin B1 lev } \\
\mu \mathrm{g} / \mathrm{kg}\end{array}$ & $\begin{array}{l}\text { es with } \\
>20\end{array}$ \\
\hline Toll-milled & 79.17 & \\
\hline Commercial feeds & 65.0 & \\
\hline Commercial brand A & 30.0 & \\
\hline Commercial brand B & 100.0 & \\
\hline Commercial brand $\mathrm{C}$ & 100.0 & \\
\hline
\end{tabular}

percent $(95 \%)$ of samples exceeding $10 \mu \mathrm{g} / \mathrm{kg}$ and while $35 \%$ exceeded $100 \mu \mathrm{g} / \mathrm{kg}$ levels ranging from $5.13-1123 \mu \mathrm{g} / \mathrm{kg}$ (Okoh \& Kola, 2012). In another study, 324 samples of grains, finished animal feeds and other feed commodities were collected from thirteen countries in the Middle East and Africa and tested for various mycotoxins including aflatoxins (Rodrigues et al., 2011). Fumonisins were the main contaminant per country in all the samples collected except for samples from Nigeria and Kenya which had aflatoxins as the main contaminant. The prevalence and the mean concentrations of aflatoxin were 94 and $78 \%, 115$ and 52 $\mu \mathrm{g} / \mathrm{kg}$ respectively, for Nigeria and Kenya (Bryden, 2012). These findings, however, showed that AFB1 contamination of feed is a worldwide problem and Nigeria is not an exception as this study had shown high level of contamination and mean concentrations of AFB1 in poultry feeds marketed in South-Eastern Nigeria.

Aflatoxin B1 prevalence in agricultural products such as cereals and grains, and hence animal feeds compounded from these agricultural products is relatively higher in 


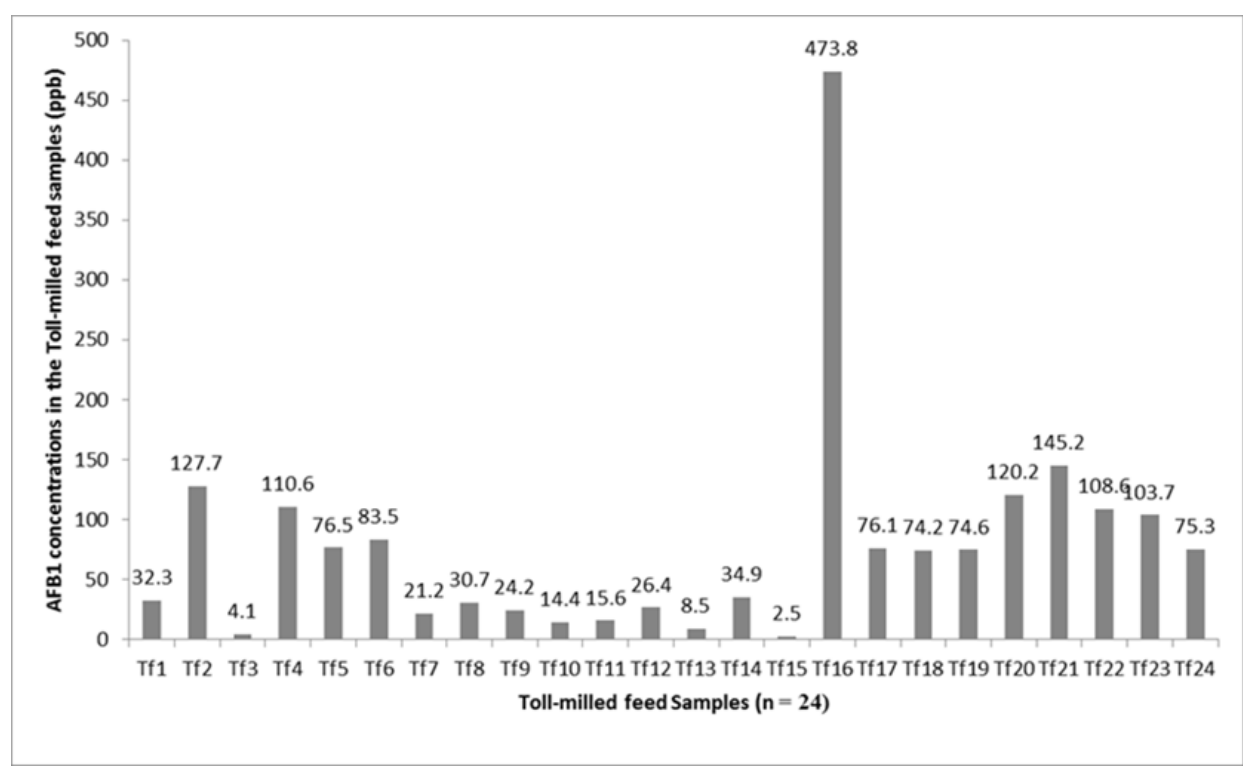

Figure I: Aflatoxin B1 concentrations (ppb) in the Toll-milled feed samples from Nsukka Agricultural zone, Enugu State, Nigeria.

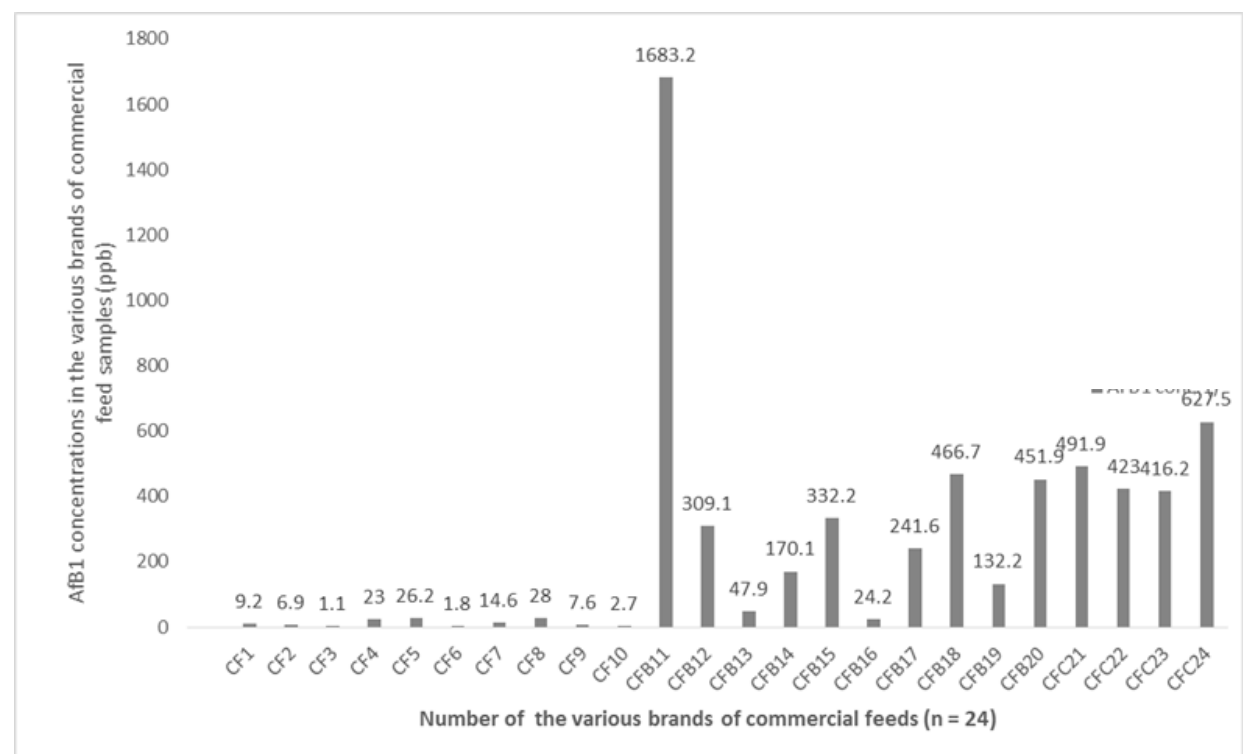

Figure II: Aflatoxin B1 Concentrations in the various brands of commercial feed samples marketed in Nsukka Agricultural zone, Enugu State, Nigeria toxigenic fungal infection and mycotoxin production arise from a complex interaction between temperature, substrate, moisture, carbon dioxide and oxygen concentration and presence of fungal spores. The optimum condition for Aspergillus species to grow is between $25^{\circ} \mathrm{C}$ to $30^{\circ} \mathrm{C}$ and relative humidity of $80 \%$ to $99 \%$ (Giorni et al., 2009). The mean daily temperature in Enugu state, Nigeria is $26.7^{\circ} \mathrm{C}$ and the relative humidity of $85 \%$, which are optimal environmental conditions for fungal growth and aflatoxin production. It is possible that the higher mean and level of contamination of the commercial feed brands by AFB 1 than the toll-milled feeds could be attributed to the longer storage time of grains and ingredients by the commercial feed producers under conditions that favour the proliferation of mycotoxigenic fungi than toll-milled feeds. However, most farmers that use tollmilled poultry feeds usually purchase some or most of the feed raw materials from the source whereas the commercial feed producers, being concerned with profit made, usually purchase sub-standard feed ingredients in bulk at a cheaper price, thereby, maximizing profit to the detriment of the farmers using their feeds. Also, the commercial feed producers are not adequately monitored by any regulatory agency so as to ascertain the safety of the ingredients being used in production, unlike the toll-milled feed producers that are always under the close watch of the farmers. Thus, the toll-milled feed producers seem to be more conscious of the quality of the feed ingredients used than the commercial feed producers. Egal et al. (2005) reported that there is a widespread AFB1 contamination of common feed ingredients in Africa: in Benin and Togo, feed grade cereals (Abidin et al., 2011). Both the toll-milled feeds and commercial feeds producers mainly use stored grains in the formulation of their feeds. For stored grains, 
AFB1 levels in maize averaged five times the safe limit of 20 $\mathrm{ppb}$ in up to $50 \%$ of the household grains.

Overall, $79.17 \%$ of toll-milled feeds and $70.8 \%$ of commercial feeds analysed contain aflatoxin B1 concentrations above the National Agency for Food and Drug Administration and Control (NAFDAC) and European Union $(20 \mu \mathrm{g} / \mathrm{kg})$ tolerance level of aflatoxin in grains for animal consumption (WFO, 2001). Similar high percentage of contamination $(73 \%)$ of poultry feeds were reported to have exceeded the FAO/WHO tolerable level of $5 \mu \mathrm{g} / \mathrm{kg}$ in Morogoro, Tanzania. These levels may negatively affect the performance of poultry and may end up in poultry meat and human food with deleterious consequences to human health. The wide range of aflatoxin B1 concentrations of the commercial feed samples were contrary to the findings from other studies conducted on commercial poultry feeds from Nigeria (Oluwafemi et al., 2009), Iraq (Shareef, 2010), and feed ingredients from South Africa (Cynthia et al., 2012) and Ethiopia (Ayelew, 2010).

Prolonged consumption of feeds with unsafe levels of AFB1 has grievous public health implication, which calls for control and regulation in animal feed formulation/consumption. Aflatoxin B1 is immunosuppressive, nephrotoxic and hepatocarcinogenic (Bhat \& Vasanthi, 2003). The desired control and regulation of mycotoxins can be achieved by reducing fungal infection of crops by rapid drying and correct storage of the harvested crop using effective antifungal preservatives.

The induction of cancer by aflatoxins has been extensively studied. Aflatoxin B1, aflatoxin M1, and aflatoxin G1 have been shown to cause various types of cancer in different animal species (Fink-Grammels, 2003). The results reveal that most of the feeds were unsafe for animal consumption. Hence, the need for setting maximum levels of aflatoxins in feeds and foods in Nigeria is generally recommended. Yun yun et al., (2015) published the comparative data of total aflatoxin limit in food among different regions worldwide: in Africa $10 \mu \mathrm{g} / \mathrm{kg}$; Asia/Ocenian $15 \mu \mathrm{g} / \mathrm{kg}$; Europe $5 \mu \mathrm{g} / \mathrm{kg}$; Latin America $20 \mu \mathrm{g} / \mathrm{kg}$ and North America 15 - $20 \mu \mathrm{g} / \mathrm{kg}$. The mostly used limit is $4 \mu \mathrm{g} / \mathrm{kg}$ (applied in 29 countries); another frequently used limit is at $20 \mu \mathrm{g} / \mathrm{kg}$ and is applied in 17 countries (half of them in Latin America and several in Africa) (CAC, 2014). Setting of internationally agreed maximum tolerable levels for aflatoxins in feed is of global importance.

The findings from this study provided evidence that there are aflatoxin b1 problem in this locality. There is need to build awareness to the feed processors, sellers and farmers on better way to alleviate occurrence of aflatoxin B1 in poultry feeds.

\section{ACKNOWLEDGEMENT}

The authors are grateful to Dr Lava Kumar and Laboratory Technologists, of Germplasm Health Unit, and Virology and Molecular Diagnostics Unit of International Institute of Tropical Agriculture, Ibadan, for their technical support throughout this work.

\section{CONFLICT OF INTEREST}

The authors declare no conflict of interest.

\section{REFERENCES}

Abdullah, A. N., Khaled, A. O. \& Ahmed, K. S. (2010). Monitoring of aflatoxin and heavy metals in some poultry feeds. African Journal of Food Science, 4(4), 192-199.

Abidin, Z., Khatoon, A. \& Numan, M. (2011). Mycotoxins in broiler: pathological alterations induced by aflatoxins and ochratoxins, diagnosis and determination, treatment and control of mycotoxicosis. World's Poultry Science Journal, 67, 485-496.

Atherstone, C., Grace, D., Lindahl, J. F., Kang'ethe, E. K. \& Nelson, F. (2016). Assessing the impact of aflatoxin consumption on animal health and productivity. African Journal of Food, Agriculture Consumption, Nutrition and Development. 16(3), 10949-10966.

Ayelew, A. (2010). Mycotoxins and surface and internal fungi of maize from Ethiopia. Journal of Food, Agriculture, Nutrition and Development, 10 (9), $4109-4123$.

Bhat, R. V. \& Vasanthi .S. (2003). Mycotoxin food safety risk in developing countries. International Food Policy Research Institute (IFPRI), (2010 vision brief 10(3), pp.34

Bryden, W. L. (2012). Mycotoxin contamination of the feed supply chain: implications for animal productivity and feed security. Animal Feed Science and Technology, 173(2), 134-158.

Codex Alimentarius Commission (CAC, 2014). Codex general standard for contaminants and toxins in food and feed. Codex standard 193 - 1995. Accessed 23. April 24 at http://www.codex alimentarius.net.

Cynthia, A.C., Suretha, D. K., Judith, Z. P., Mulunda, M., Mary, A. E. \& Michael, F. D. (2012). Fungal and mycotoxin contamination of South African commercial maize. Journal of Food, Agriculture and Environment, 10 (2), 296 - 303.

Denli, M. \& Okon, F. (2006). Efficacy of different adsorbent in reducing the toxic effects of aflatoxin B1 in broiler diets. South African Journal of Animal Science, 36(4), 222-228.

Egboka, B. C. (1985). Water resource problems in the Enugu area of Anambra state Nigeria. Water resources and environmental pollution unit (WREPU). Scientific basis for water resources management (proceedings of the Jerusalem Symposium, 1985). IAHS publ. no. 153 , pp. 98. 
FAO. (1993). Sampling plans for Aflatoxin analysis in peanut and corn. FAO Food and Nutrition paper 55, pp. 55 - 75. Codex STAN 209.

Fink-Grammels, J. (2003). Quality objectives in animal nutrition. In World Nutrition forum. BiominFGmstt, Austria, pp.49-50.

Giorni, P., Magna, N. \& Battilani, P. (2009). Environmental factors modify carbon nutritional patterns and niche overlap between Aspergillus flavus and Fusarium verticilliodes strains from maize. International Journal of Food Microbiology, 130(3), 213-218.

Herzallah, S. M. (2009). Determination of aflatoxins in eggs, milk, meat and meat products using HPLC, Fluorescent and UV Detectors. Food Chemistry, 114(3), $1114-1146$.

Kajuna, F. F., Temba, B. A. \& Mosha, R. D. (2013). Surveillance of aflatoxin B1 contamination in chicken commercial feeds in Morogoro, Tanzania. Livestock Research for Rural Development, 25 (3), $45-51$.

Lava, K. \& Bandyopadhyay, R. (2012). Afla-ELISA: A test for the estimation of aflatoxin. (Lava Kumar and Katherine Lopez, eds) IITA R4D Review, $8^{\text {th }}$ edition, pp. 45-47.

Leggieri, M. C., Bertuzzi, T., Pietri, A., \& Battilani, P. (2015). Mycotoxin occurrence in maize produced in Northern Italy over the years 2009 - 2011: focus on the role of crop related factors. Phytopathologia Mediterranea, 54(2), 212-221.

Magnoli, P., Monge, M. P., Miazzo, R. D., Cavalieri, L. R., Magnoli, C. E., Merkis, C. I., Cristofolini, A. L., Dalcero, A. M \& Chiacchiera, S. M. (2011). Effects of low levels of aflatoxin B1 on performance, biochemical parameters and aflatoxin $\mathrm{B} 1$ in broiler liver in the presence of monensin and sodium bentonite. Poultry Science, 90(1), 48-58.

Marchioro, A. A., Mallmann, A. O., Diel, A., Dilkin, P., Rauber, R. H., Blazquez, F. J. H. \& Oliveira, C. M. (2013). Effects of aflatoxins on performance and exocrine pancreas of broiler chickens. American Association of Avian Pathologists, 57(2), 280-284.

Mostafa, A., Armin, A., Hamid, P. \& Reza, A. M. (2012). Review paper: Rapid detection methods for analysis of fungi and mycotoxins in Agricultural products. Research Journal of Recent Sciences, 1(7), 90 - 98.

Muhammad, A., Faqir, M. A., Masood, S. B., Imran. P., Muhammad, A. R., Farhan, S. \& Khalid, W. (2013). Aflatoxins occurrence, toxicity, and remedies. Food Science and Nutrition, 53(8), 862 - 874.

Odoemela, S. A \& Osun, C. I. (2009). Aflatoxin B1 contamination of some edible grains marketed in Nigeria. E-journal of Chemistry, 6(2), 308-314.

Oliveira, G. R., Ribeiro, J. M., Fraga, M. E., Cavaglieri, L. R., Direito, G. M., Keller, K. M., Dalcero, A. M. \& Rosa, C. A. R. (2006). Mycobiota in poultry feeds and natural occurrence of aflatoxins, fumonisins and zearalenone in the Rio de Janeiro state, Brazil. Mycopathologia, 162(5), 355-362.

Oluwafemi, F., Kehinde, M. T., Elegbede, F. F., Alafia, O. M. \& Dike, C. C. (2009). Determination of aflatoxin levels in commercial poultry feeds sold in some part of Southwestern Nigeria. $A n$ International Journal of Agricultural sciences, Sciences, Environment and Technology, 8 (1), 202 208.

Okoh, S. A. \& Kola, M. A. (2012). Market Samples as a source of chronic aflatoxin exposure in Kenya. African Journal of Health Science, 20(1-2), 56 - 61.

Oyekemi, O. A., Abdul-Dahiru El-Yuguda, Rudolf-Krska (2012). Mycotoxins in poultry feed ingredients in Nigeria. Mycotoxin Research, 35, 419 - 155.

Reddy, B. N. \& Raghavender, C. R. (2007). Outbreaks of Aflatoxicoses in India. African Journal of Food, Agriculture, Nutrition and Development, 7 (5), 1 15.

Rodrigues, I., Handl, J. \& Binder, E. M. (2011). Food Additives and Contaminants: Part B: Surveillance on Mycotoxin occurrence in commodities, feeds and feed Ingredients sourced in the Middle East and Africa. Food Additives and Contaminants: Part B, 4(3), $168-179$.

Shareef, A. M. (2010). Molds and mycotoxins in poultry feeds from farms of potential mycotoxicoses. Iraq Journal of Veterinary Science, 24(1), 17-24.

Tola, M. \& Kebede, B. (2016). Occurrence, importance and control of mycotoxins. A review: Cogent Food and Agriculture, 2(1), 1 - 12.

Trusksess, M. W. (2001). Rapid analysis (Thin layer chromatographic and immune-chemical methods) for mycotoxins in foods and feeds. In W. J. de Koe, R. A. Samson, H. P. van Egmond, J. Gilbert and M. Sabino. Mycotoxins and phytotoxins in perspective at the turn of the millennium. Proceedings of the tenth International IUPAC symposium on mycotoxins and phytotoxins, gauraga, Brazil.

Varga, J., Frisvad, J. C. \& Samson, R. A. (2011). Two new aflatoxin producing species and overview of Aspergillus section Flavi. Study in Mycology, 69(1), 57 - 80.

WHO (World Health Organization) (2006). Mycotoxins in African foods; implications to Food Safety and Health. AFRO Food Safety Newsletter, 2 Rome, pp. $1-10$.

World Food Organization (WFO) (2001). Discovery and occurrence of the Fumonisin: A historical perspective. Environmental Health perspectives supplements, 109 (Suppl2), 239-43.

Yun yun, G., Michael. R., Martin, E., Kimanya, G., Musoke, F., Stanley, S. \& Victor, M. (2015. Building an Aflatoxin safe East African community. Technical policy paper 8. Aflatoxin standards for food knowledge platform 2015 situational analysis East Africa Region.

Article history:

Received: June 29, 2021,

Revised: Oct. 15, 2021

Accepted: Nov. 11, 2021 